\title{
What Makes a Good Politician? Reassessing the Criteria Used for Political Recruitment
}

Certain societal groups are significantly overrepresented within politics, including men, ethnic majority groups, and socio-economic elites. This has fuelled debates regarding meritocracy within political recruitment. While meritocracy is desirable, its definition and measurement are contested. The criteria used in theoretical and empirical academic studies differ from those of political parties and voters. Furthermore, there is bias in favor of the male status quo, with all groups preferring the qualities of existing elites. The definition of a "good" politician is therefore highly subjective. Nonetheless, political traditionalists claim that the "best" candidate should be selected even if this leads to significant gender imbalance in parliaments. Yet, if political recruitment is biased in favor of social elites, the overrecruitment of men may not derive solely from merit (Murray 2014). Without definitive criteria for evaluating prospective candidates and judging those already elected, we cannot determine whether political recruitment is meritocratic.

\section{Criteria in Political Theory}

Political theorists question whether representatives should be trustees exercising independent decision-making, or delegates following their constituents' demands (Eulau et al 1959). An ideal representative would think independently and make wise decisions, while also consulting with constituents and including their perspectives. Limitations are imposed by the widespread ignorance and heterogeneity of public opinion. Nonetheless, the imperative of re-election stops politicians ignoring their constituents. A politician can be an authentic representative only through understanding others' perspectives enough to act on their behalf and with their consent.

Pitkin (1967) explores descriptive, substantive and symbolic representation. Descriptive representation is conceptualized at the group level, if representatives' demographic traits mirror those of society. Individual representatives descriptively represent constituents sharing their demographic features. Substantive representation entails representing interests rather than identities, although the latter frequently shape the former. Descriptive representation can facilitate substantive representation, although it is neither necessary nor sufficient (Reingold 2008; Swers 2005). Symbolic representation ensures that all groups feel included.

Mansbridge (2003) introduces gyroscopic and surrogate representation. Gyroscopic representatives base decisions on their own beliefs and experiences. As external influences seldom shape their opinions, this concept of representation would be problematic without descriptive representation. Surrogate representatives may speak for groups outside their districts who share their characteristics, such as African Americans (Brookman 2013). Both approaches favor diversity and balance across the whole legislature.

Dovi (2007) provides a normative framework for assessing the quality of representatives, arguing that a "good representative" should display fair-mindedness, critical trust building, and good gatekeeping. Together, these "virtues" are effective for evaluating the democratic efficacy of representatives. However, their benefit is limited when defining meritocratic candidate selection criteria, as they measure the performance of those already in office, and it is harder to demonstrate these qualities prior to election. 
Overall, insights from theorists focus on latent attributes which are measurable only indirectly through evaluating observable activity. This disadvantages unelected outsider groups, including women, who lack opportunities to demonstrate their competence.

\section{Criteria in Empirical Studies}

Empirical studies focus on concrete qualities that can be measured easily and objectively, but are inaccurate predictors of legislator quality. Numerous studies claim that better educated politicians will be more intelligent, knowledgeable, and will make better policies (Baltrunaite et al 2014; Besley and Reynal-Querol 2011; Galasso and Nannicini 2011). However, educational attainment may derive from socio-economic privilege and may also be gendered. The knowledge obtained through advanced qualifications can be provided by aides, whereas true understanding of deprivation will be absent if legislatures are composed only of elites. This awareness gap reduces the efficacy and legitimacy of legislatures, especially if representatives use gyroscopic representation that reflects their own rather than their constituents' experiences. Likewise, income is a poor proxy for candidate competence. Women collectively are paid less than men irrespective of skills, and earned income may also stem from privilege and social capital.

Other measures of qualification for office include prior political and professional experience (Murray 2010b; O’Brien 2012; Verge 2011; Weeks and Baldez 2015). Prior political experience demonstrates commitment, knowledge and a track record, though it may reflect longevity rather than talent. It also favors men, as women often avoid entering politics during their child-rearing years. Professional experience may again favor those with elite backgrounds, and certain professions benefit political careers through expedience rather than inherently qualifying someone for office. These measures of merit therefore require refinement.

\section{Party Criteria}

Party candidate selection practices vary considerably by culture, internal democracy, ideology, and nationality. Practice may also vary within the party, even when codified guidelines on candidate selection exist. Nonetheless, research has revealed some commonalities in party selectorates' expectations of prospective candidates, including contributing campaigning resources (Hazan and Rahat 2010; Kittilson 2006). As men typically enjoy greater free time and higher incomes than women, this criterion indirectly favors men. Parties also expect candidates to support their message and demonstrate loyalty. Voters may appreciate party loyalty, as this enables them to vote on national party manifestos and hold governments accountable. However, some constituents may be frustrated if a candidate's loyalties lie with the party rather than the district.

Additional desirable attributes include charisma; eloquence; public speaking skills; good media presence; intelligence; and good networks (Murray 2010a). The ideal candidate unites the party faithful while drawing in a wider electorate. These seemingly neutral attributes conceal socially constructed biases against women that manifest themselves through gendered evaluations of candidates, negative media coverage of women, and less (self) belief in women's strengths (Lawless and Fox 2010; Norris and Lovenduski 1995). Networks may also work against women, especially when men collude together (Bjarnegård 2013). 


\section{Voter Criteria}

The qualities sought by voters are somewhat different. Experimental studies reveal interesting voter preferences for certain types of candidates. The perceived sex of the candidate influences how voters evaluate candidates' traits and policy strengths, with women considered warmer and more honest, while men are seen as tougher and more rational (Alexander and Andersen 1993; Huddy and Terkildsen 1993). Other studies have identified strong voter preference for candidates who are local (Campbell and Cowley 2014a; Górecki and Marsh 2012), indicating that voters want geographical descriptive representation. Yet, emphasizing localism can been used to close ranks against 'outsiders' such as female or ethnic minority candidates (Cowley 2013).

High levels of income, education, and high-status professions do not actually improve candidates' status with voters (Campbell and Cowley 2014a, 2014b). Voters do like representatives to spend ample time in the constituency (Campbell and Lovenduski 2014; Vivyan and Wagner 2015), indicating that voters want their representatives to be accessible delegates rather than trustees. Voters also want someone "like them," sharing their experiences and interests, as well as supporting more diversity (Campbell and Cowley 2014b; Cowley 2013). Hence, descriptive representation may better reflect voter preferences than the elitist conceptions of candidate quality advanced by scholars. Shared backgrounds and genuine understanding of constituents' lives may better qualify candidates for office than elite status.

\section{Conclusion}

Within politics, unlike other professions, being the "best" representative may therefore entail communicating honestly and effectively what it is to be "average." If we seek talented representatives who can also speak authentically for us, this requires politicians whose backgrounds and experiences are common rather than exceptional. Conventional measures of merit matter less than personal qualities, though these are subjective and difficult to measure, entailing two particular risks. First, pervasive stereotyping may lead certain types of candidate (such as women or ethnic minorities) to be evaluated less highly. Second, criteria for evaluating candidates are shaped by path dependence and societal norms, both of which favor existing elites (Bacchi 1996; Young 2000). When we think of a (good) representative, we usually imagine a wealthy white male (Norris and Lovenduski 1995). By internalizing norms of class, race, and gender, we unconsciously favor the status quo.

For example, we might prefer a successful businessman to a childcare worker, even though the latter might have more expertise on education, healthcare, welfare, and family policy. By focusing on managing the economy rather than thinking about the full policy spectrum, we subscribe to the dominant masculinist model of politics. We prioritize the policy areas associated with wealthy men, and assume that wealthy men can best advance these issues. As Taylor notes, "one way discrimination is perpetuated is by the dominance of elite white men over... what counts as merit" (1991: 233, original emphasis), leading us to overlook important alternative qualities found in women (Franceschet et al 2012: 11).

The search for a valid, unbiased, and measurable definition of meritocracy remains incomplete. Theoretical qualities are abstract while empirical measurements are arbitrary, and 
neither provides sufficient measures of candidate merit. Education, income, and profession are imperfect proxies for latent qualities such as charisma, eloquence, or intelligence, and they cannot disentangle attainment from privilege. In contrast, parties and voters use subjective judgments, increasing the risk of bias. A possible agenda for future research is to decouple theory from current practice, and return to first principles. Focusing on what representation is and what it really requires of a candidate would be a first step towards a more objective definition of "merit."

\section{References}

Alexander, Deborah, and Kristi Andersen. 1993. "Gender as a Factor in the Attribution of Leadership Traits." Political Research Quarterly 46(3): 527-545.

Bacchi, Carol. 1996. The Politics of Affirmative Action. California: Sage.

Baltrunaite, Audinga, Piera Bello, Alessandra Casarico, and Paola Profeta. 2014.

"Gender Quotas and the Quality of Politicians." Journal of Public Economics 118: 62-74.

Besley, Timothy, and Marta Reynal-Querol. 2011. "Do Democracies Select More

Educated Leaders?" American Political Science Review 105(3): 552-566.

Bjarnegård, Elin. 2013. Gender, Informal Institutions and Political Recruitment.

Basingstoke: Palgrave.

Brookman, David E. 2013. "Black Politicians are More Intrinsically Motivated to

Advance Blacks' Interests.” American Journal of Political Science 57(3): 521-36.

Campbell, Rosie, and Philip Cowley. 2014a. "What Voters Want: Reactions to

Candidate Characteristics in a Survey Experiment." Political Studies 62(4): 745-65.

Campbell, Rosie, and Philip Cowley. 2014b. "Rich Man, Poor Man, Politician Man:

Wealth Effects in a Candidate Biography Survey Experiment." British Journal of Politics and International Relations 16(1): 56-74.

Campbell, Rosie, and Joni Lovenduski. 2014. "What Should MPs Do? Public and Parliamentarians' Views Compared." Parliamentary Affairs Advance Access.

Cowley, Philip. 2013. "Why Not Ask the Audience? Understanding the Public's Representational Priorities." British Politics 8(2): 138-63.

Dovi, Suzanne. 2007. The Good Representative. Malden, MA: Blackwell.

Eulau, Heinz, John C. Wahlke, William Buchanan, and Leroy C. Ferguson. 1959.

"The Role of the Representative: Some Empirical Observations on the Theory of Edmund

Burke.” American Political Science Review 53(3): 742-756.

Franceschet, Susan, Mona Lena Krook, and Jennifer M. Piscopo, eds. 2012. The

Impact of Quotas on Women's Descriptive, Substantive, and Symbolic Representation. New

York: Oxford University Press.

Galasso, Vincenzo, and Tommaso Nannicini, 2011. "Competing on Good Politicians." American Political Science Review 105(1): 79-99.

Górecki, Maciej. A, and Michael Marsh. 2012. "Not Just 'Friends and Neighbours':

Canvassing, Geographic Proximity and Voter Choice." European Journal of Political Research 51(5): 563-582.

Hazan, Reuven Y., and Gideon Rahat. 2010. Democracy within Parties. Oxford:

Oxford University Press.

Huddy, Leonie, and Nayda Terkildsen. 1993. "Gender Stereotypes and the Perception of Male and Female Candidates." American Journal of Political Science 37(1): 119-147.

Kittilson, Miki Caul. 2006. Challenging Parties, Changing Parliaments. Ohio State University Press. 
Lawless, Jennifer, and Richard L. Fox. 2010. It Still Takes a Candidate: Why Women Don't Run for Office. Cambridge: Cambridge University Press.

Mansbridge, Jane. 2003. "Rethinking Representation." American Political Science Review 97(4): 515-28.

Murray, Rainbow. 2010a. Parties, Gender Quotas and Candidate Selection in France. Basingstoke: Palgrave.

Murray, Rainbow. 2010b. "Second Among Unequals: A Study of Whether France's 'Quota Women' are Up to the Job.” Politics \& Gender 6(1): 93-118.

Murray, Rainbow. 2014. "Quotas for Men: Reframing Gender Quotas as a Means of Improving Representation for All.” American Political Science Review, 108(3): 520-32.

Norris, Pippa, and Joni Lovenduski. 1995. Political Recruitment. Cambridge: Cambridge University Press.

O'Brien, Diana Z. 2012. "Quotas and Qualifications in Uganda." In The Impact of Quotas, eds. Susan Franceschet, Mona Lena Krook, and Jennifer M. Piscopo. New York: Oxford University Press, 57-71.

Pitkin, Hanna. 1967. The Concept of Representation. Los Angeles: University of California Press.

Reingold, Beth. 2008. "Women as Office Holders: Linking Descriptive and Substantive Representation." In Political Women and American Democracy, eds. Christina Wolbrecht, Karen Beckwith, and Lisa Baldez. New York: Cambridge University Press, 12847.

Swers, Michele L. 2005. "Connecting Descriptive and Substantive Representation: An Analysis of Sex Differences in Co-Sponsorship Activity." Legislative Studies Quarterly 30(3): 407-433.

Taylor, Bron R. 1991. Affirmative Action at Work. Pittsburgh, PA: University of Pittsburgh Press.

Verge, Tania. 2011. "Cuotas de Género y Reclutamiento Politico. Análisis del Parlament de Catalunya, 1980-2010.” Revista Española de Ciencia Política 26: 87-104.

Vivyan, Nick, and Markus Wagner. 2015. "What do Voters Want from their Local MP?" Political Quarterly Early View.

Young, Iris Marion. 2000. Inclusion and Democracy. Oxford: Oxford University Press.

Weeks, Ana Catalano, and Lisa Baldez. 2015. "Quotas and Qualifications: The Impact of Gender Quota Laws on the Qualifications of Legislators in the Italian Parliament." European Political Science Review 7(1): 119-44. 